\title{
Analysis of Syekh Taqiyuddin An-Nabhani's Idea on Public Assets Privatization
}

\author{
Dodi Okri Handokoํㅜ Juliana Juliana², Fahmy Lukman ${ }^{3}$ \\ ${ }^{1}$ Department of Accounting Sciences, Faculty of Economics and Business, Universitas Islam Riau, Pekanbaru, Indonesia \\ ${ }^{2}$ Department of Islamic Economics and Finance, Faculty of Economics and Business Education, Universitas Pendidikan Indonesia, \\ Bandung, Indonesia \\ ${ }^{3}$ Department of Arabic Literature, Faculty of Culture Sciences, Universitas Padjadjaran, Sumedang, Indonesia
}

ARTICLE INFO

\section{Keywords}

Taqiyuddin, Privatization,

Ownership

\section{*Correspondence}

dodiokri@eco.uir.ac.id

\section{Article History}

Received 22 February 2021

Accepted 26 June 2021

Published online 27 June 2021

\section{ABSTRACT}

In Indonesia, public asset privatization policy has been valid since the Oil and Gas Law Number 22 the Year 2001. The objectives of this research were: (1) To determine the criteria for public assets according to the idea of Syekh Taqiyuddin An-Nabhani., (2) To find out the Islamic economic analysis of the idea of Syekh Taqiyuddin An-Nabhani on the privatization of public assets. The data source of this research is secondary data, which were taken from literature and books from research correlating to the object of this study and other required data. The data analysis in this research is descriptive. First, various data collected were analyzed using content analysis technique (content analysis), then the study and analysis of the data are carried out to obtain the conclusions. After conducting the research and analysis, it is concluded that (1) Syekh Taqiyuddin An-Nabhani classifies public assets based on the types of ownership, namely public ownership and state ownership, (2) Islam strongly prohibits the management of public assets through privatization. However, it is returned to the State, and its use by the public is permitted by shara'.

\section{INTRODUCTION}

Islam is a universal and comprehensive religion. The perfection of Islam in regulating all aspects of human life encompasses the spiritual aspect and the Muamalah aspect, including economic, social, political, law, and so forth (Mawardi, 2007; Janin \& Kahlmeyer, 2015). One of the economic issues that are regulated is the issue of public assets ownership through privatization. Privatization, in a broad sense, as suggested by Kay and Thompson (1986), is a "means of changing relationship between the government and private sector" (privatization is a way of changing the relationship between the government and the private sector). Meanwhile, Pas, Lowes, and Davies define privatization in a narrow sense, namely the denationalization of industry, changing from government ownership to private ownership (Pas, Lowes, \& Davies, 1998).

Privatization is the transfer of ownership of assets that the State previously controls to private property (Lane \& Kinser, 2011). For the asset, ownership refers to the privatization of collective property. Syekh Taqiyuddin An-Nabhani criticizes the privatization of public assets (public ownership), which came out from the ideology of Capitalism-Liberal, then he offered solutions and views of Islamic Economics in the ownership issue itself.

In Indonesia, the privatization policy of public assets (natural resources) has been going strong since the Oil and Gas Law Number 22 the Year 2001. Since then, the public has been treated by various chaotic information regarding oil and gas management almost every year. Philosophically, the passage of the oil and gas law as a background for the privatization of public assets is a policy that is contrary to the 1945 Constitution, especially Article 33, because of the practice of privatization that occurs many natural resources are controlled and enjoyed by only a handful of people (Marlina, Juliana, Adila \& Rabbani, 2019).

According to BPMIGAS, Indonesian Oil and Gas Management Agency, (2012), there are 29 blocks of 72 Oil and Gas (Migas) in the country which contracts will expire until 2021. There are Block Siak (Riau) with the operator Chevron Pacific Indonesia, which will expire in 2013, Mahakam Offshore Block (East Kalimantan) with operator Total E\&P Indonesia (2017), Sanga-Sanga Block (East Kalimantan) with contractor VICO and Southeast Sumatra Block, which is managed by CNOOC (2018). In addition, in the Bula Block (Maluku) with the Kalrez operator (2019), the South Jambi B Block managed by Conoco Phillips (2020), and the Muriah Block (Central Java) managed by Petronas (2021).

Government policies have consistently favored private companies, both local and foreign, so there have been many reactions from the public. For example, in 2012, 3 cases came to public attention due to government policies that took sides with foreigners,

(C) 2021 by the authors; licensee PRIMA, Hannover, Germany. This is an Open Access article distributed under the terms of the Creative Commons Attribution-ShareAlike 4.0 International License.(https://creativecommons.org/licenses/by-sa/4.0/), which permits unrestricted use, distribution, and reproduction in any medium, provided the original work is properly cited. 
including the Siak Block Case in Riau, which was eventually asked to be managed by BUMD, the Tangguh Block case in Papua, which was exchanged for the "Gelar Kesatria Salib" and the most shocking case was the Mahakam Block posed a threat of "disintegration" from the people of East Kalimantan to separate from Indonesia if the Mahakam Block was still given to foreigners (BPMIGAS, 2012). Thus, the problems in this research are: (1) What are the criteria for public assets according to the idea of Syekh Taqiyuddin AnNabhani? (2) How is the analysis of Islamic economics on the idea of Syekh Taqiyuddin An-Nabhani regarding the privatization of public assets?

\section{RESEARCH METHODS}

This research is included in library research (Nazir, 1998). In conducting research, both field research and library research requires an accurate method so that the results can be accepted academically and scientifically. Several techniques are used in writing scientific papers: (1) Deductive, namely disclosing general data related to the problem under the study, then analyzing it so that specific conclusions can be drawn. (2) Inductive, namely disclosing and providing specific data, then the data is interpreted so that a general conclusion can be drawn. (3) Descriptive, which explains what is, thereby giving an overview of the research. From some of the scientific writing techniques above, this research used two writing techniques: (1) Deductive Method, which collects general principles to be elaborated and draws specific conclusions. (2) Analytical Descriptive Method is a way of collecting data that is considered to be related to the problem under study and then described systematically.

\section{RESULTS AND DISCUSSIONS}

\subsection{The form of public assets according to Syekh Taqiyuddin An-Nabhani}

According to the idea of Syekh Taqiyuddin An-Nabhani, the discussion on public assets is discussed in the ownership chapter (milkiyyah), which is collective property. Ownership is one of the pillars of Islamic economics. The determination of ownership (milkiyyah) is one of the pillars because by nature, humans have the right to utilize existing assets for the benefit of their life (Yusanto \& Yunus, 2009).

According to Al-Habibi (2008), the term "ownership" comes from the Arabic word "milk", which means property. The term "milk" might refer to having something and being able to act freely against it (Hasan, 2015; Razak \& Saupi, 2017). The term "milk" can be defined as an ikhtisas that hinders others, according to the shari'ah, which justifies the owner of the ikhtisas to act (tasharruf) against his belongings at will, unless there is a barrier to possession (as-Suyuti, 1983; Ishaq, 2015; Khalid, Nyborg, \& Khattak, 2015). It hinders having it, maybe because it is not included in the people allowed to manage it, such as children (as-Suyuti, 1983). As for the forms of public assets according to the idea of Syekh Taqiyuddin An-Nabhani (1996) are as follows:

\subsubsection{Public Facilities}

According to Syekh Taqiyuddin An-Nabhani (1996), what is meant by public facilities is everything considered in the interests of humans in general. In this case, the Prophet SAW once said which set the limits of public facilities. From Ibn Abbas, RA (n. d., as cited in Al-Bani, 2005), said that the Prophet SAW said:

$$
\text { المسلمون شركاء فى ثلاث في الكلاء والماء والنار }
$$

"Muslims are allied (have equal rights) in three ways; fields, water, and fire" (HR. Abu Dawud).

In another history, Ibn Abbas RA said that the Prophet SAW said:

$$
\text { المسلمون شركاء فى ثلاث فن الكلاء والماء والنار وثمنه حرام }
$$

"Muslims are allied (have equal rights) in three ways; fields, water, and fire" (HR. Anas).

It was narrated by Ibn Majjah (n. d., as cited in Yazid, 2015) from Abu Hurairah RA that the Prophet SAW said:

$$
\text { ثلاثة لا يمنعنالماء والكلاء والنار }
$$

"There are three things that will never be forbidden (for anyone to have); water, fields and fire" (HR. Ibn Majjah)

Syekh Abdul Qadim Zallum also explained that what is meant by public facilities is public property, which includes the first type of public facilities needed for all Muslims in daily life. If there is not there, it causes disintegration, such as water. Rasulullah SAW has explained the characteristics of these public facilities, and he explained them in detail and perfection. This refers to the Prophet SAW's hadiths regarding the public facilities themselves (Zallum, 2004).

Water, pasture, and fire were the first treasures allowed for humankind. They unite in it and prohibit them from owning any part of this public facility because it is the right of all Muslims (Dariah, Salleh, \& Shafiai, 2016). A people may come down to get drinking water on their way, as well as stop in a part of the desert area that is overgrown with plants-where Allah SWT has grown it for their livestock-provided that the area is not an area that someone has cultivated, is not planted, and also not the source of drinking water (i.e., the area belonging to someone who has arrived there first) and not belonging to someone specifically, so that other people besides him may not have it, but is an area where they drink their livestock, a place to replenish their drinking water supply, as well as the small animals, were there (Zallum, 2004; Hasan, 2015).

For this first category, where everyone is unionized, this treasure is not limited to the three types mentioned in the above hadiths. Still, it includes every object in which there are characteristics of the public means themselves.

Rasulullah SAW had let the people of Khaibar and Taif have their wells privately. They drank from the wells, fed their animals and livestock, and watered their gardens. Rasulullah SAW allowed them because the well was small and not related to public 
facilities. By combining these two types of hadith, it is clear that water becomes public property when it comes to public means and is forbidden to own it privately. However, if the water is scarce and not related to public facilities, it is permissible for someone to own it privately.

Observing precisely what is called a public facility is that all humans need it in their daily life. Therefore, if the facility is lost, then people are sorted out and try to find it. This situation is similar (to the condition) of every tribe that divided when they lost water or grazing land for their animals and livestock (Fawaz, 2014). Therefore, everything related to public means is needed by humans in their daily life, and they will be divided when they lose it, so this matter is public property.

According to Syekh Abdul Qadim Zallum, the thing that is included in the type of public ownership is an instrument used in it because the law and ownership status is the same, namely as public property. Therefore, the means for extracting water for public use from springs, wells, rivers, lakes as well as tools for channeling water, and the channels that connect it to houses, including public property, are following the status of the water they issue; its distribution and distribution to people's homes, also belong to the public. Unless these tools are made over large lakes and rivers, such as the Nile or the Euphrates, they may become private property and be used privately (Zallum, 2004).

As the power plants are built on (sources) of water for public use, such as canals and rivers and supporting poles, their wire networks, and stations are public property. This is because these tools generate electricity from the public property so that the legal status of these tools is the same, namely public property (Hasan, 2015).

Likewise, the power plants and their stations, the supporting poles, and the wire networks are public property - although electricity is generated through these devices - if electricity is obtained from the fuel process. Generally, this is the case, and so is the light that it generates. The same electricity is used for cooking, heating, running factory equipment, or smelting mining metal. At that time, the function of electricity was the same as fire, while the fire was part of public property. So, the means of production, the stations, the other devices, the supporting poles, and the wired network are the same, are public property (Zallum, 2004).

It is the same as the natural gas and coal industries are also classified as public ownership based on the characteristic of the nature of natural gas and coal, which are public property. Because of the condition (which is natural) is a valuable mineral and part of the fire (Zallum, 2004). Meanwhile, according to M. Ismail Yusanto and M. Arif Yunus, public facilities included in the collective property criteria are public facilities that are very large in number and needed by the general public. If the number is limited, such as small wells in the village or so on, then the well can be owned by an individual, and in this condition, the well water belongs to the individual Yusanto \& Yunus, 2009. Based on the description above, it is clear that something in the public interest is anything that if it is not fulfilled in a community, anywhere, whether in a village or a city, then the community will dispute it. Therefore, these objects are considered public facilities.

\subsubsection{The unlimited quantities of mineral}

According to Sheikh Taqiyuddin An-Nabhani (1996), the category of public ownership of unlimited mineral can be seen from the following sentence:

$$
\text { أماالمعدن, فهى قسمان: قسم محدود المقدار بككمية لا تعتبر كمية كبيرة بالنسبة للفرد, وقسم غير محدود المقدار }
$$

Regarding mineral (natural resources) as a general ownership category, it can be classified into two things; (1) limited quantity of mineral, not much according to individual size; and (2) unlimited amount of mineral From the verse above, it is understood that according to Syekh Taqiyuddin An-Nabhani that mineral which is included in the category of public ownership are mineral which is unlimited in quantity. However, a limited mineral is not included in public ownership, so it can be owned by an individual and becomes an individual property (private property). Thus, for a limited number of minerals and individuals are allowed to own it, the law of rikaz (zakat of mineral) applies - in which there are $1 / 5$ of the assets which must be issued zakat from the acquisition of these assets.

According to Syekh Taqiyuddin An-Nabhani (1996), the existence of an unlimited number of minerals as the public property includes all minerals; both visible minerals, which can be obtained without any effort and which they can use, such as salt, antimony, precious stones and so on; or minerals that are in the bowels of the earth, which cannot be obtained other than by hard work such as gold, silver, iron, copper, tin and so on; both solid and liquid such as kerosene. This can be seen from the following sentence:

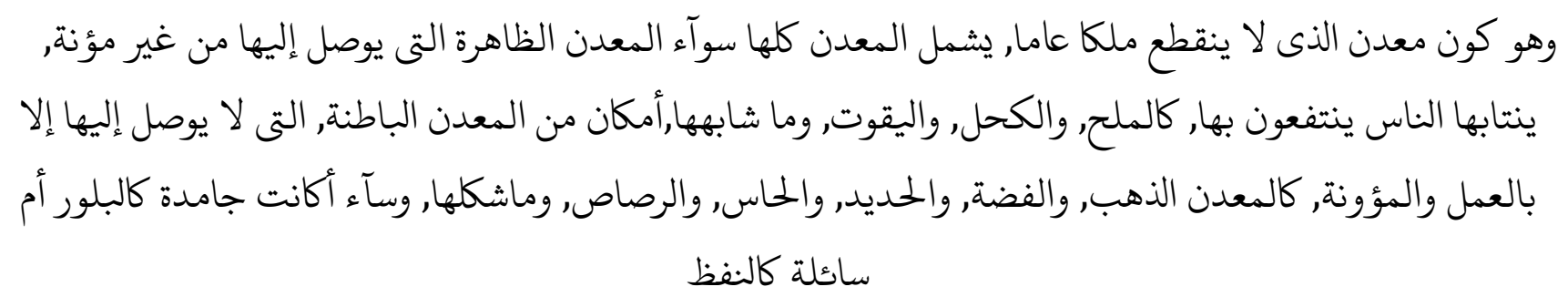

From the verse above, it is known that Syekh Taqiyuddin An-Nabhani in discussing minerals that can be grouped into public property, where the minerals are not seen from the point of view of whether or not it is difficult to get the minerals. However, whether the mineral is a minor or small quantity or vice versa, the minerals are in large quantity. In this case, he divides the minerals into visible and easily accessible forms, and there are large quantities of minerals in the earth's bowels; to get it requires great effort. 
In discussing the criteria for the minerals that can be grouped into public property, Syekh Abdul Qadim Zallum explained that the number of minerals is unlimited; is mineral whose amount (deposit) is very abundant. But, on the other hand, minerals (deposits) are minor, and the amount is very limited is classified as private property so that someone may own it (Zallum, 2004).

According to Syekh Abdul Qadim Zallum, mining gold, silver, and other mining goods with tiny amounts (deposits) - not economical and not for trading - is classified as private property. Therefore, someone may own it, and for the State, they can give mining goods like that to them. It's just that they are obliged to pay khumus (one-fifth) of (goods) produced to Baitul Maal, whether the exploited is minor or a lot (Zallum, 2004).

Then, in discussing mining goods that are included in the category of public property assets, Syekh Abdul Qadim Zallum distinguishes between open-pit mining goods (found in the earth's surface) whose exploitation does not require serious effort, such as salt mining or (stone) eye shadow; with mining goods found in the bowels of the earth, whose exploitation requires serious effort, such as gold, silver, iron, copper, graphite, tin, chromium, uranium, phosphate and other mining goods. Likewise, whether in solid forms (ore) such as gold and iron, or liquid forms such as petroleum, or gas such as natural gas (Zallum, 2004).

Based on the opinion above, it can be understood that mining goods that are included in the category of public ownership are mining goods in large quantities, either visible or open without the need of effort to get it or in the bowels of the earth; who take effort to get it, both in the form of liquid and solid. Therefore, it is caused by the mining goods that can be classified as public property are mining goods that are not seen from the nature, form, and method of obtaining them. However, these mining goods are measured in terms of the quantity of the mining goods themselves.

\subsubsection{The Natural Resources which The Formation Prevents Individual Control against It}

The third category of public ownership is natural resources whose formation prevents individual control. According to Syekh Taqiyuddin An-Nabhani (1996), these are objects that include public benefits. This can be seen from the following sentence:

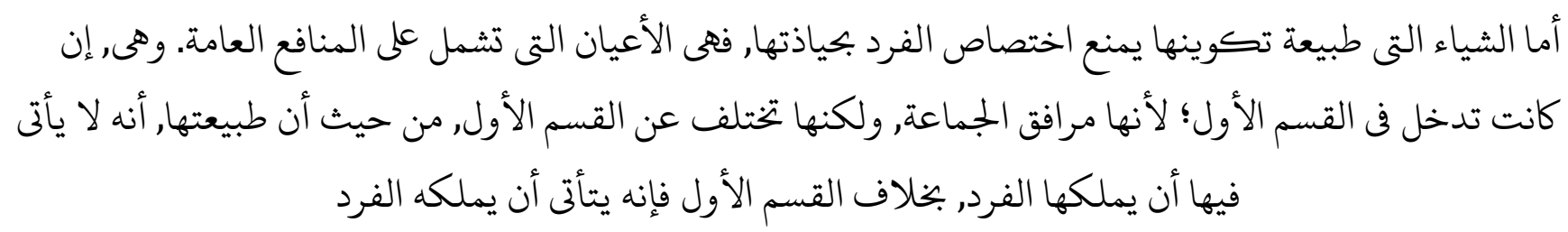

The objects whose formation prevents to own privately are objects that include public benefit. Although these objects are included in the first group, because they are public facilities, they differ from the first group in their nature, namely that individuals cannot own them. This is different from the first group, which individuals can own. For example, liquid substances can indeed be owned by individuals. However, individuals are prohibited from owning it if a community needs water. This is different, for example, roads, because roads are not possible owned by individuals.

The verse above shows that public ownership, which is included in the third category, has been stipulated by shari'a to prevent someone from owning it, although individuals may own something. However, the property is prohibited for individuals to own because the public needs these resources.

According to Abdurrahman al-Maliki, if this type of public property is public facilities like ownership of the first type, the argument includes public facilities. But, this second type is based on the origin of its formation prevents a person from owning it, so it is permissible to have the necessities of the public (al-Maliki, 2001).

Meanwhile, according to Syekh Abdul Qadim Zallum, the public ownership of the third type is in the form of public facilities like ownership of the first type, then the argument is that the argument includes public facilities. It's just that this second type according to the origin of its formation - prevents a person from owning it. The condition is different from the first type which the origin of its formation does not prevent someone from owning it - for example - they may personally own a small well (spring) that does not interfere with the needs of many people (Zallum, 2004).

Then, it was explained further by Syekh Abdul Qadim Zallum that there is no control/fencing of public property except by the State. The meaning of this hadith is that one cannot control something that belongs to all humans for himself. The trains, trams, electric supporting poles, water lines, water pipes located on public roads are public property, so their condition must still be made part of the public road. The act of taking over a part of the public road permanently and singling out the individual for control over time is the same as mastery. It cannot be controlled/fenced off except by the State. Everything mentioned earlier is public property (Zallum, 2004).

From the description above regarding the criteria for public property assets, it can be concluded that Islam provides clear boundaries of public property, so that these limitations make individuals and communities, in seeking and collecting assets, let the wealth obtained, not just obtaining property in terms of quantity or physicality but also the assets obtained are truly lawful and a blessing. Then, the apparent limitations of ownership of the assets help the government carry out the political economy in a country. Thus, in the management and control of assets, the State (government) is not wrong in making a policy, by giving individuals the right not only to use the public property but also to give the right to control these assets, through privatization of natural resources or assets public. Because Islam has decided that public property cannot be controlled or owned by individuals, but only have the right to use it.

\subsection{The Privatization of Public Assets}

In Babylon English Arabic Dictionary, the Privatization is:

$$
\text { الخصخصة, جعل الشيء خاص؛ نقل الملكية من الحكومة إلى أيد أشخاص }
$$

"Privatization is making something to be private property or transferring state ownership to private property forever". 


\section{خص خص, جعل الثىء خاص, نقل التحكى من قوى حكومية إلى أفراد؛ تغيير عمل أو صناعة من الملكية$$
\text { العامة إلى تحككم فردى أو ملكية فردية. }
$$ \\ Privatization is to specialize something or transfer government management to remote control or change the collective property to private property.}

From several kinds of literature, experts in defining the meaning of privatization, both broadly and narrowly. In a broad sense, privatization refers to changing the relationship between the government and the private sector (Kay \& Thompson, 1986; Fatima \& Rehman, 2012). Meanwhile, privatization in a narrow sense, as defined by Pas, Lowes, \& Davies (1998), is the denationalization of industry, changing from government ownership to private ownership. Meanwhile, according to Dunleavy in Bastian, privatization is a permanent transfer of goods and services production activities carried out by state companies to private companies or in the form of non-public organizations, such as non-governmental organizations (Bastian, 2002). Likewise, Pirie defines privatization as the transfer of public goods and services to the private sector. This shift has resulted in a change in the management of public sector companies to private mechanisms (Bastian, 2002).

In Basley and Littlechild's view, although the word privatization can generally be interpreted as 'company formation', according to the Company Act Privatization, privatization is defined as a continuing sale of at least $50 \%$ of the shares owned by the government to private shareholders. So, the idea of privatization is a concept of industrial development by increasing the role of market power (Bastian, 2002).

A common thread is drawn from the various definitions above that privatization transfers assets (ownership) that the State previously controls to become private property. This definition of privatization is by Law Number 19 the Year 2003 about BUMN (state-owned enterprise). In article 1 section 12 of the BUMN constitution, it is stated that privatization is the sale of shares of Persero (Limited Liability Company), either partially or entirely, to other parties to improve company performance and value, increase benefits for the State and society and expand shares by the public (BUMN, 2003). Based on current facts, many countries, especially those still in the developing category, have implemented policies to privatize public assets. Many countries are implementing these policies that cannot be separated from the shift in views on the State's role in regulating the economy. According to Rahmat S. Labib, the privatization policy is a local policy designed globally (Labib, 2005).

From his analysis, two factors encourage the policy of privatization of public assets or public ownership, namely: First; internally; the privatization policy got the legality of law and constitution in a country, such as Indonesia, the existence of Law Number 19 the Year 2003 concerning BUMN which was passed on June 19, 2003. Second, externally; the factors that encourage privatization in a country are issues, and the global trend towards a free market (free market) and a more prominent role of the economy; with the assumption that the assets owned are mainly carried out by the private sector (private sector) (Labib, 2005).

According to Filomilo Sta Ana, externally, the courage to privatize public assets was caused by pressure from multilateral institutions that played an essential role in implementing various privatization policies in various countries (Ana, 1999). Meanwhile, according to Roy, the privatization policy in a country was caused by pressure from international financial institutions such as the World Bank, IMF, world economic recession, oil price instability, and so on (Sembel, 1998). Based on various opinions from economic experts, the privatization policy of public assets is a global scenario planned and carried out by a superpower country (in power) in controlling the natural wealth of a country. Thus, privatization closely relates to a country's ideology, considering that the privatization policy was not born from a vacuum. However, it is in a mainstream capitalist economic system that promotes economic liberalization and free markets.

Theoretically, the capitalist system only recognizes one form of ownership, namely private property. Therefore, the privatization policy aims to provide opportunities for capital to own and control various public assets by themselves.

In Indonesia, the privatization policy of public assets (natural resources) has been going strong since the enactment of the Oil and Gas Law Number 22 the Year 2001. Since then, the public has been treated to chaotic information regarding oil and gas management in this country almost every year. According to Oil and Gas Implementing Agency (BP Migas), there are 29 blocks of 72 Oil and Gas (Migas) in the country whose contracts will expire until 2021. They are Block Siak (Riau) with the operator Chevron Pacific Indonesia, which will expire in 2013; Mahakam Offshore Block (East Kalimantan) with operator Total E\&P Indonesia (2017), Sanga-Sanga Block (East Kalimantan) with contractor VICO and Southeast Sumatra Block managed by CNOOC (2018). In addition, in the Bula Block (Maluku) with the Kalrez operator (2019), the South Jambi B Block managed by Conoco Phillips (2020), and the Muriah Block (Central Java) managed by Petronas (2021).

Government policies have consistently favored private companies, both local and foreign, so there have been many reactions from the public. In 2012, 3 cases came to the attention of the public due to government policies in favor of the case, the Siak Block case in Riau, which BUMD eventually managed, the Tangguh Block case in Papua, which was exchanged for the "Gelar Kesatria Salib" and the most shocking was the Mahakam Block case which it came out the threat of "disintegration" from the people of East Kalimantan if the Mahakam Block is still given to foreigners (BPMIGAS, 2012). From the description above, it is clear that almost every island in Indonesia has public assets, and these assets have been controlled by foreigners or individuals (privatization) utilizing privatization. The control of these public assets is a permit that has been granted by the state (government) through a stipulated law.

The permits granted to local and foreign private companies for new mines or contract extensions for those already in progress, such as the Mahakam Block, Tangguh Block, which was given to British Petroleum, a gold mine in Irian Jaya which was given to PT. The United States of Freeport and thousands of other contracts of work always lead to two classic reasons put forward by the government: the inability of Pertamina and other BUMNs from the technical side and the inability of the capital side (Hidayatullah, 2012).

The technology and capital issues are often the classic reasons for the government to hand over oil and gas exploration to foreign parties. However, the first problem, namely oil and gas exploration technology, and mineral and coal exploration, is not the main problem. Pertamina and other BUMNs have been able to carry out oil and gas and mineral and coal exploration both onshore 
(land), offshore (offshore), and in the deep sea (deep water). On share is a form of exploration on land. Pertamina, with its domestic experts, has been able to detect and explore it without any hindrance. For example, the discovery of oil reserves in the Cepu Block is an expert from Pertamina. Pertamina also states that it is technologically capable of exploring it without foreign assistance (Hidayatullah, 2012).

On the other side, offshore oil and gas exploration in marine areas, both offshore, shallow sea, and deep sea. Pertamina often has been doubted about its capabilities in offshore oil and gas exploration and is even considered incapable of both technology and capital. However, it is proven that Pertamina can explore the West Madura Block, even the results have increased compared to the Oil and Gas Implementing Agency (BP Migas) (Hidayatullah, 2012).

For the capital aspect, if the government or Pertamina does not have funds, many financial institutions or banks can guarantee credit disbursement if Pertamina has an underlying asset (guarantee). Primarily if this is supported by government guarantees through the ownership of national oil and gas reserves by Pertamina as a state-owned company like other countries, such as Venezuela or Malaysia through its Petronas.

In the middle of complaints and concern over government policies regarding the management of natural resources, especially oil and gas, the Constitutional Court provided good news by granting Islamic organizations and several figures against the existence of the Oil and Gas Law and BP Migas. The impact of the cancellation of several articles in the Oil and Gas Law and the basis for the existence of BP Migas, such as Article 1 number 23 and other articles, is the dissolution of BP Migas. Some people think that the dissolution of BP Migas can restore state sovereignty over oil and gas (Hidayatullah, 2012). Based on the description above, it is understood that the essence of oil and gas liberalization that provides opportunities for the privatization of natural resources is not actually in the existence of an institution such as BP Migas. The essence of liberalization lies in Article 9, paragraph 1, stating that Upstream and Downstream Oil and Gas Businesses "can be implemented by: State-Owned Enterprises; Regional owned enterprises; Cooperative; Small business; Private Business Entity. " The word "can" in article 9 paragraph 1 causes the position of BUMN to be equated with BUMS (Private Owned Enterprises). With this equalization of positions, BUMN loses its oil and gas management privileges, which the constitution should have given as the State's hand in managing natural resources or public assets.

Furthermore, if the Oil and Gas BUMN wants to manage an oil and gas block, it must participate in a tender with other BUMS. The results are extraordinary. Nearly $90 \%$ of our oil resources are controlled by the private sector, both local and foreign. In fact, for this year's budget, according to the Minister of BUMN, Dahlan Iskan, foreign contractors still dominate $75 \%$ of oil and gas projects in the country. Even though BP Migas is dissolved, if this article 9 still exists, then oil and gas privatization and liberalization will continue.

Technology and capital are not the main issues. Moreover, as the only BUMN in the oil and gas sector, Pertamina has no less excellent capabilities than foreign companies. The main issue is the government that does not side with the people but with global capitalists. This is proven in several cases in this country, such as Cepu Block oil and gas mine or the gold mine, Freeport, and Newmont.

For example, in the Cepu Block and Freeport, Cepu Block was easily handed over to Exxon-Mobile due to pressure from the US government. At the same time, the gold mine in Irian Jaya continued to be controlled by Freeport. As a result, the wealth in this country cannot be controlled and utilized optimally by its people.

There are currently 60 oil and gas contractors in oil and gas management, which are categorized into three groups. First: Super Major, consisting of Exxon-Mobile, Total Fina Elf, BP Amoco Arco, and Texaco, which control 70\% oil reserves and 80\% gas reserves. Second: Major, consisting of Conoco, Repsol, Unocal, Santa Fe, Gulf, Premier, Lasmo, Inpex, and Japex, which control 18\% oil reserves and $15 \%$ gas reserves. Third: independent companies; controls $12 \%$ oil reserves and $5 \%$ gas reserves (Hidayatullah, 2012).

In the case of PT. Freeport Indonesia, from the mine in Papua itself, Indonesia should have received a profit of Rp 50-100 billion per year, when the State manages the management of mines which are public assets, not the private sector, through privatization. On the other hand, Japanese companies also enjoy most nickel mining because nearly 53\% of the Japanese nickel industry's needs are supplied from nickel mining products from Indonesia. Therefore, the government does not side with the people or is not by shari'ah arises from the mindset of the government, which is liberal and capitalistic, thus becoming the privatization of public assets. This was supported by the DPR, which apply liberal and capitalistic laws and regulations such as the Oil and Gas Law Number 22 the Year 2001 and the Minerba Law Number 4 the Year 2009 (Hidayatullah, 2012).

\subsection{Islamic Economic Analysis of the Idea of Syekh Taqimuddin An-Nabhani on the Privatization of Public Assets}

Chapter I explained in chapter I in the research method section that this research is library research, namely by examining books and writings, including examining books that result from Taqiyuddin An-Nabhani's idea on privatization of public assets. In this case, the writer collects the various data needed, and then the data is analyzed using content analysis techniques (content analysis), namely studying the messages that exist in various literature starting from vocabulary, sentence patterns, and situation backgrounds. In analyzing the ideas of Sheikh Taqiyuddin An -Nabhani about the privatization of public assets, the writer always makes shara' law (shari'a rules in economics) as the basis for analyzing these ideas. Then compare his ideas with other scholars who also discuss the same topic and problem: the privatization of public assets.

\subsubsection{The Privatization of Public Assets According to Syekh Taqiyuddin An-Nabhani}

Based on the discussion that has been previously described, it is known that in discussing the privatization of public assets, Syekh Taqiyuddin An-Nabhani discussed, in general, the concept of ownership is public ownership. From his thinking, it is known that public ownership is the right of all Muslims, which Ash-Shari has determined ', but in its management, it is submitted and entrusted to the caliph (State), then the results are returned to the Muslims in the form of facilities and services. Thus, all types of assets that are included in the category of public ownership assets, individuals are prohibited from controlling and managing them, but individuals are allowed to take advantage of the results of the management. Therefore, based on the description above, the privatization of public assets is included in public ownership, which is a policy and a forbidden act. 


\subsubsection{The Privatization According to Economic Scholars and Thinkers}

From the description above, the opinions of Islamic economic scholars and thinkers about the privatization of public assets and the ideas of Syekh Taqiyuddin An-Nabhani that it is known that there are no differences in opinion of other scholars (such as Sheikh Abdul Qadim Zallum, Abdurrahman Al-Maliki, and others) with the ideas of Syekh Taqiyuddin An-Nabhani on the matter of privatization of public assets. From the work of Islamic economic scholars and thinkers as previously described above, it is understood that scholars and other Islamic economic thinkers are relevant to the ideas of Syekh Taqiyuddin An-Nabhani in the issue of privatization of public assets. The prohibition of privatization of public assets according to scholars and other Islamic economic thinkers, because observing the various activities and policies of the ruler (State) to privatize public assets, because privatized public assets are assets that fall into the category of public property assets; and there is no right or reason for the individual (someone) to control and own the asset. However, an individual (someone) is only given the right to take advantage of the results of his management in the form of facilities and services provided by the State (ruler).

\subsubsection{The Analysis of The Researcher}

From the literature review that has been done by the writer on the ideas of Syekh Taqiyuddin An-Nabhani about the privatization of public assets, it is known that the prohibition on managing public assets are included in the category of public ownership is due to the existence of texts clearly and firmly in their management.

The policy of transferring public assets belonging to public property to private ownership is a policy that is contrary to Islamic economics; and contrary to (hadith) Rasulullah SAW; in the management of these assets. In this case, Ash-Shari gave authority to the State (caliph) in managing it; The results of managing these assets are returned to the people (the society) in the form of facilities and services. The provision of facilities and services to the community by the State is a form of obligation and the role that the State must play in economic matters. According to M. Arif Yunus, there are several roles and state policies in economic matters, namely: 1) Formulating and planning economic policies, 2) Management of public and State property rights, 3) Maintaining market mechanisms; 4) Supervision and punishment of economic crimes (Yusanto \& Yunus, 2004).

The roles and policies above are one of the obligations carried out by the State, as explained by Ibn Taimiyyah, where the state and state leadership are an Islamic obligation. To regulate all public affairs is an obligation. It cannot be built without good State institutions. There are so many cases that are the obligation of all Muslims that cannot be carried out without State institutions because they require strength, organization, and authority. For example, Jihad and law enforcement cannot be appropriately handled without involving the role and power of the State (Islahi, 2005). Based on the provisions above, all forms of public assets and their derivatives are included in the category of BUMN engaged in the mining and energy industry, such as PT Aneka Tambang, PT Tambang Timah, PT Tambang Batu Bara are absolute and must not be privatized. This is confirmed by the category "fire" stipulated in the Hadith of the Prophet SAW. "Humans are united in three things: water, pasture, and fire ..."; Because what is meant by "fire" is fuel and everything related to it, so that oil, natural gas, tin and coal, and all their exploration tools are included in the public ownership.

In this context, the State is not only prohibited from privatizing these state-owned enterprises but is also obliged to revoke mining goods management permits that have already been granted to private parties. From this case, the Indonesian government is obliged to revoke the exploration permit of the giant foreign oil company Exxon through PT. Caltex and PT. Freeport Indonesia in Papua, which manages a gold mine. This is different from PT. Semen Gresik and PT. Krakatau Steel, whose production status can be owned individually, can privatize it provided that the shares sold must not exceed 55\%. Although individuals can own these companies' products, they can affect the prices of other goods, such as house prices, rental prices, construction prices, and so on.

In the telecommunication and transportation services sector involving PT. Telkom and PT. Indosat, which provides telecommunication services, can be classified into the state ownership type even though they are included in public affairs and ownership services. Even if this type of service already has competitors from the private sector, the State still has to provide services to its citizens in this field. It is hoped that this will provoke and lead to healthy competition, which will continue to increase the business of these services to customers and lead to competitive prices. This is different if PT. Telkom and PT. Indosat is the only player in this sector, in other words, PT. Telkom is the only company that handles cable telephones in Indonesia.

In the sea and air transportation services sector, PT. Angkasa Pura and PT. Pelindo II and III can also be classified under public ownership because the sea and air are public property, so that ports and airports as berths are also classified as public property. So that, the company also cannot be privatized, including PT. KAI and PT. Jasa Marga. This is different from PT PELNI, which manages sea transportation services because ships can be owned individually from the type of vehicle. Even though in terms of infrastructure, the sea is a type of public ownership, in its operation, it does not prevent anyone from considering the vastness of the ocean (compared to railways, so the ownership status is different).

In the plantation and forestry sector, PT. Perkebunan Nusantara can be classified into state ownership types but can be privatized. This is because land can be owned individually, so ownership of agricultural and plantation businesses is also individual. This is different from the forestry sector, a type of public ownership that cannot be privatized. Privatization of the agricultural and plantation sectors is allowed if the State can guarantee the stability of the prices of agricultural and plantation products. Still, if the government cannot provide this guarantee, it is better not to privatize it.

Based on the description above, it is understood that Syekh Taqiyuddin An-Nabhani's idea about the privatization of public asset management, which is included in the category of public ownership (private property), is an act that is forbidden by shara' because shara' has determined and allowed each individual to own it and the management should submit to the State, not to each individual through privatization. The prohibition actions that the government takes in privatizing public assets are caused by several things, namely: First, the State is not entitled to sell public ownership assets because these assets are not his property, but public property. Islam has prohibited the sale of an item that the seller does not own. If this kind of sale occurs, the sale is not legal. The hadith of the Prophet Muhammad (n. d., as cited in al-Bani, 2005) stated that:

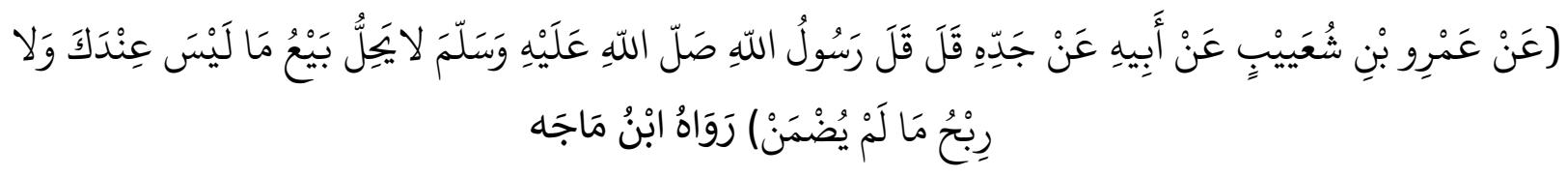

www.jkpis.com 
"From Amr ibn Shu'aib from his father from his grandfather he said, "Rasulullah SAW said: "It is not lawful to sell something that you do not have, and it is not permissible to take advantage of something that you do not have, and may not take advantage of something that is not clear being guaranteed yet (clarity of law)". (HR. Ibnu Majah: 2187)

Second, privatization causes the property to circulate only among the rich, both individuals and companies. Thus, the people cannot take advantage of these assets, and the distribution of wealth will be increasingly unbalanced. This is not justified according to Islam, as Allah SWT says:

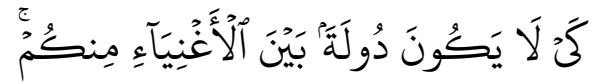

"Let the treasure not circulate only among the rich" (QS al-Hashr [59]: 7)

Indeed, the verse above forbids the circulation of wealth only among the rich among Muslims (aghniyaâ minkum). However, this verse also applies to the rich among the infidels. Because if wealth cannot only be circulated among wealthy Muslims, it is not allowed to only circulate among rich kafirs. It is based on the practice of mafhum muwafaqah in the science of ushul fiqih.

Third, privatization creates domination and hegemony of the kafirs over the Muslims. By this privatization, capitalist individuals or companies will later dominate and control Islamic countries, both economic and political. Islamic countries will be caught in the grip of economic imperialism. Islam forbids this, Allah SWT says:

"And Allah will never make way for the disbelievers to destroy those who believe" (TQS. An-Nisa' [4]: 141)

Ibn Katsir (2008) stated that "let us not open up opportunities in all aspects, which allow the infidels to control the Muslims. From this statement, it is obvious here that the capital sector is a public asset. If an infidel controls it, it will result in total economic control. It can be so up to political domination, which could destroy humankind (Azarqo, 1988).

Fourth, privatization is an intermediary (wasilah) for the emergence of harm for Muslims. As explained earlier, privatization will cause unemployment due to layoffs, increase poverty due to reduced employee salaries, eliminate sources of state income, burden consumers with inflated prices or tariffs due to high taxes on privatized companies, squander the country's wealth on the non-productive sector, prevents the people from utilizing public property assets, and provides an opportunity for the entry of attacks by capitalist thought and culture on the Muslims. All of this constitutes harm and disadvantage that Islam prohibits. Therefore, privatization, which leads to that direction, is also forbidden. Zuhdi (1992) stated that:$$
\text { الوسيلة إلى الحرام حرام }
$$ \\ "All means are prohibited, the law is also haram".}

Even though privatization is advertised to produce benefits, privatization creates and has harmful effects, negating and erasing the profits. According to Zuhdi (1992), several dangers or losses resulting from privatization (public assets) are:

Centralized assets of a country in the agricultural, industrial, and trade sectors to a handful of individuals or companies with large capital and sophisticated management, technology, and strategy. This means that the majority of the people are prevented from obtaining and utilizing these assets. These assets ended up circulating only among the rich. Thus, privatization will exacerbate the poor distribution of wealth. This has been evident in capitalist countries, especially the United States and Europe.

Privatization in Islamic countries with opening doors to foreign investors, both individuals and companies, means plunging Islamic countries into the grip of economic imperialism. This is because these capitalist individuals or companies that will later dominate and control Islamic countries. Furthermore, there will be a robbery of the wealth of Islamic countries and at the same time for the strengthening of political domination over the government and people of these Islamic countries. Foreign investors will only seek the maximum profit in the shortest possible time, regardless of people's needs for goods and services. They will also ignore efforts to revive the industries of Islamic countries. Ironically, some Islamic countries that obey privatization provisions have given foreign investors the strategic title partner. Of course, the intention is to show that they are good while hiding their true nature.

The transfer of ownership, especially in the industrial and agricultural sectors, from state / public ownership to individual ownership, will generally result in layoffs or reduced employee salaries. This is because investors in the capitalist economic system tend to think that layoffs or reducing employee salaries are the easiest and fastest ways to reduce production costs and improve product quality. In turn, the number of unemployed and poor people will increase. Even though it is well known that unemployment and poverty significantly affect the condition of society, the level of production, and economic growth.

Abolishing public ownership or state ownership means that the State releases itself from its obligations towards the people. The State will not be able to carry out many responsibilities it should bear because the State has lost its sources of income. The State will no longer be able to fulfill the basic needs of the poor perfectly. The State will also no longer be able to properly fulfill the people's health and education needs, and so on.

The State will be busy looking for new sources of income to replace the sources of income it has sold. And the State will not get any other feasible source, apart from imposing high taxes on the various factories, sectors, and business entities that it has sold or those individuals own. This will inflate the prices and tariffs that burden society. In other words, it is the consumers themselves who will pay the tax to the State, not the investors. If the State is no longer responsible for its people and unemployment increases, it will create a vulnerable and very dangerous social condition.

The State's funds from public or state ownership are generally not managed in productive sectors. Much of it will run out as desired from international institutions like the IMF to be spent on infrastructure development, environmental preservation, human resource development, etc. All of these are doors to absorb foreign capital from outside. This is an act of squandering the people's wealth by spending the people's assets for the benefit of foreign investors. 
Obstructing the society from obtaining their rights is to utilize public property assets, such as water, oil, water transportation facilities, and ports. Thus, privatization is a tyranny that damages people's livelihoods. Imam ibn Taymiyyah said the State is responsible for distributing wealth throughout society because the State only has a role in representing the ummah, not to own it (Taymiyyah, 1998).

Privatizing mass media, especially television and radio, will allow attacks on capitalist thought and culture. This poses a civilization hazard to the ummah because the ummah will be fed with the mindset and spirit of kufr, with depraved and low Western moral standards and behavior.

Based on the description and explanation of the privatization of public assets according to the ideas of Sheikh Taqiyuddin AnNabhani above, it is understood that:

As a religion of shamil and kamil, Islamic Shari'at presents an economic system that is different from other economic systems, including the capitalist and socialist systems and their parts. In this system, Islamic economics harmonizes and protects two different interests, the interests of the world and the interests of the hereafter, by involving the State as the representative of Allah on earth (khalifatullah) and at the same time as the mandate holder of all its people based on the provisions of shara' as stated in the Qur'an, al-hadith, ijma 'and al-qiyas.

Privatization in the Islamic economic system has long been known. This is permissible as long as the type of individual property ownership and some types of state property with a guarantee of price stability by the State, and not the type of property classified as public ownership. This is because Allah has provided nature and its contents for the welfare of all humankind and is not just for a few people.

Privatization is not allowed for BUMN with the following categories: First, BUMN manages public facilities that are the community's livelihood, such as the category of water, grassland, and fire. Second, BUMN manages natural resources whose formation character cannot be controlled by individuals or a specific group. The third, state-owned enterprises (BUMN) that manage mining goods with unlimited deposits, such as gold, silver, iron, copper, oil, tin, etc.

In addition, in discussing the privatization of public assets from Sheikh Taqiyuddin An-Nabhani, the writer considers that Sheikh Taqiyuddin An-Nabhani seeks to conduct a critical analysis of the concept of economic thought that exists in Islam with concepts outside of Islam; namely capitalism and socialism. Thus, from his thinking, it is found that privatization of public assets is a policy that comes up from the concept of capitalism which only recognizes one concept of ownership, namely individual ownership (private property).

Conceptually, this is contrary to Islam. It is caused that Islam does not recognize a single concept of ownership, such as individual ownership (in capitalism) and state ownership alone (in socialism). However, Islam recognizes three concepts of ownership, namely individual, public, and state ownership. Each ownership has clear boundaries and has been regulated and defined by Asy- Syari'; as described above.

The ownership in an Islamic economic perspective is one of the pillars of the economy. According to Yusanto and Yunus (2009), there are three pillars in the economy, namely (1) ownership, consisting of individual, public, and state ownership; (2) management, consisting of utilization and development. In terms of utilization, there is use for oneself, dependents, and the community. Meanwhile, development can be carried out through real economic concepts, such as trade, agriculture, industry, and services; (3) distribution of wealth to society. In this case, this is done through two mechanisms, namely the economic mechanism; and non-economic mechanisms.

The distribution of wealth, either through economic or non-economic mechanisms, has mandatory legal status, and some have sunnah legal status. Economic mechanisms with mandatory status include baitul maal (state treasury), taxes (dharibah). Meanwhile, economic mechanisms have the status of sunnah law, such as responsibility (takaful) and encouragement of qardh alhasan. As for non-economic mechanisms with mandatory legal status is; in the form of zakat and inheritance. Meanwhile, the noneconomic mechanism with the status of sunnah law is in the form of sunnah alms (Yusanto \& Yunus, 2009). Thus it is clear that the State's plans and policies in granting control and ownership of public assets through privatization of public assets; and not just the use of these assets is a policy that is contrary to the concept of Islamic economics because various public assets and their derivatives are mandates from the people (ummah) given to the ruler (State) in their management. In this case, the State may not give it to individuals or the private sector through privatization; or privatization of these public assets by handing them over to foreigners.

\section{CONCLUSION}

Based on the description and explanation in the discussion related to the privatization of public assets according to the ideas of Syekh Taqiyuddin An-Nabhani, it can be concluded that Syek Taqiyuddin An-Nabhani, a Muslim economist who lived in the 20th century, carried out studies and analysis using an ideological approach (mabda'). It was based on the idea that the economy is one of the aspects discussed in Islam; it is part of human affairs with the others. In addition, throughout his studies and analyzes, AnNabhani always refers to the sources and legal laws that have been established and agreed upon in Islam, namely based on the alQur'an, al-hadith, ijma 'friends, and qiyas.

Privatization in the Islamic economic system has long been known, and it is permissible. But, according to Syekh Taqiyuddin An-Nabhani, as far as those are the type of individual property ownership (private property) or some types of state property with a guarantee of price stability by the State, and not the type of property belonging to the collective property. Allah has provided nature and its contents for the welfare of all humankind and is not just for a few people.

In response to that argument, therefore, privatization is not allowed for BUMN (State-owned companies) with the following categories: First, BUMN that manage public facilities that are the livelihood of the community, such as the water, grassland, and fire categories. Second, BUMN manages natural resources whose formation character cannot be controlled by specific individuals or groups. Third, state-owned companies (BUMN) manage mining goods with unlimited deposits, such as gold, silver, iron, copper, oil, tin, etc.

\section{References}

Al-Bani, M, N. (2005). Shaheh Sunan Abu Daud. Jakarta: Gema Insani.

Al-Maliki, A. (2001). As-Siyasatu al-Iqtishadiyatu al-Mutsla, Diterjemahkan oleh Ibnu Sholehah, dengan judul Politik Ekonomi Islam. Bangil: Al-Izzah. 
Ana, F. S. (1999). Privatization and Goverment in The Philipines. Journal Maret.

An-Nabhani, T. (1996). Membangun Sistem Ekonomi Alternatif, Perspektif Islam. Surabaya: Risalah Gusti.

As-Suyuti. (2015). Asbah Wanazoir Fi Qowaaid Wal Furu' Lfiqih Assyafi'iyya. Beirut: Darul Kutub Ilmiyah.

Azarqo', M. A. (1988). al madkhol fi fikh al 'am juz 2, Suria: Darul Fikr.

Babylon English Arabic Translation. (1997). Yehuda: Babylon Software Ltd.

Bastian. I. (2002). Privatisasi di Indonesia: Teori dan Implementasi. Jakarta: Salemba Empat.

Dariah, A. R., Salleh, M. S., \& Shafiai, H. M. (2016). A new approach for sustainable development goals in Islamic perspective. procedia-social and behavioral sciences, 219, 159-166.

Fatima, G., \& Rehman, W. (2012). A Review of Privatization Policies in Pakistan. Interdisciplinary Journal of Contemporary Research in Business, 3(9).

Fawaz, M. (2014). The politics of property in planning: Hezbollah's reconstruction of Haret Hreik (Beirut, Lebanon) as case study. International Journal of Urban and Regional Research, 38(3), 922-934.

Habib, H. A. (1988). Qomus alfiqh, fi diyanah islamiyah. Damaskus: Darul Fikir.

Hasan, S. (2015). Islam, property and philanthropy: ethical and philosophical foundations and cultural influences. In Human Security and Philanthropy (pp. 51-74). Springer, New York, NY.

Hidayatullah. (2012). Refleksi Akhir Tahun 2012. Unpublished manuscript. Halaqoh Islam Peradaban (HIP)Hizbuttahrir Indonesia Wilayah Riau, Gedung Perpustakaan Wilayah Riau.

http://BP.Migas.org//25/12/12/kontrak-karya-migasdanminerba.html

Islahi, A. A. (2015). Economic Concepts of Ibn Taimiyah (Vol. 12). Kube Publishing Ltd.

Ishaq, M. (2015). Under the light of Quran-Hadith_Land ownership and opinion of religious leaders. The Islamic Culture" As-Saqafatul Islamia" الثقافة الإسلامين-Research Journal-Sheikh Zayed Islamic Centre, University of Karachi, (34), 30-51.

Janin, H., \& Kahlmeyer, A. (2015). Islamic law: The Sharia from Muhammad's time to the present. McFarland.

Katsir, I. (2008). Tafsir alquranul aziem. Beirut: Darul Tiebah.

Kay, J. A., \& Thompson, D. J. (1986). Privatisation: a policy in search of a rationale. The economic journal, 96(381), 18-32.

Khalid, A., Nyborg, I., \& Khattak, B. N. (2015). Whose property whose authority? Gendering the legal and customary practices in ownership and access to land: A case of Swat, Pakistan. Journal of Rural Studies, 41, 47-58.

Labib, R. S. (2005). Privatisasi Dalam Pandangan Islam. Jakarta: WADI Press.

Lane, J. E., \& Kinser, K. (2011). Reconsidering privatization in cross-border engagements: The sometimes public nature of private activity. Higher Education Policy, 24(2), 255-273.

Majah, I., \& Yazid, M. I. (2015). Sunan Ibn Majah.

Marlina, R., Juliana, J. J., Adila, N. A., \& Robbani, M. B. Islamic Political Economy: Critical Review of Economic Policy in Indonesia. Review of Islamic Economics and Finance (RIEF), 2(1), 44-52.

Mawardi. (2007). Ekonomi Islam. Pekanbaru: Alaf Riau Graha UNRI Press.

Nazir. M. (1998). Metode Penelitian. Jakarta: Ghalia Indonesia.

Pas, C., Lowes, B., \& Davies, L. (1998). Kamus Lengkap Ekonomi, Diterjemahkan oleh Tumpul Rumapea dan Posmon Haloho. Jakarta: Penerbit Erlangga.

Qudamah, I. (2010). Almughni. Riyad: Dar Ala'mul Kutub.

Razak, L. A., \& Saupi, M. N. (2017). The concept and application of damān al-milkiyyah (ownership risk). ISRA International Journal of Islamic Finance, Vol. 9 No. 2, pp. 148-163. https://doi.org/10.1108/IJIF-06-2017-0002

Sembel, R. H. M. (1998). Privatisasi BUMN di Indonesia dalam Mengembangkan Strategi Ekonomi. Jakarta: Pustaka Sinar Harapan.

Taymiyyah, I. (1998). Siyasah Assar'iyyah Fi Islahi Raa'i Wa Ro'iya. Qatar: Idarotu Su'unil Islamiyah.

Yusanto, M. I., \& Yunus, M. A. (2009). Pengantar Ekonomi Islam. Bogor: Al-Azhar Press.

Zallum, A. Q. (2004). al-Amwal fi al-Daulah al-Khilafah. Beirut: Darul Ummah.

Zuhdi, M. (1992). Masail Fiqhiyyah. Jakarta: Haji Masagung. 